\title{
BINATIONAL MARRIAGES AND MULTICULTURAL EDUCATIONAL ENVIRONMENT
}

\author{
Ewa Sowa-Behtane \\ Jesuit University Ignatianum in Krakow, Poland
}

\begin{abstract}
Today, in the era of post-modernity, the ethnically, racially, religiously, culturally or nationally mixed marriages are more and more frequent phenomenon, contributing to the emergence of new types of cultural identity. Nationally mixed marriages (binational) define a new cultural quality when they do not concern only individuals, but when they become a phenomenon which is statistically frequent, and even dominant in a broader social context. The aim of the current project is an academic description of binational marriages which have been concluded by spouses from different nationalities, and thus characterized by different culture, tradition, mother tongue, and often religion and race, one of them being the representative of Polish culture.
\end{abstract}

Keywords: binationalism, educational environment, foreigners, integration marriage, multiculturalism, multilingualism, multireligious.

\section{Introduction}

In the era of globalization, meeting people from different cultural circles on one's way of life has become a common phenomenon. Additionally, after joining the European Union, Poland has become a 'matrimonially' attractive country for non-EU citizens who may acquire Polish citizenship through marriage. The processes of entering into intercultural relations in the territory of Poland will intensify. We could say that in Polish society a significant social change is taking place, a change 'from homogeneity to heterogeneity, from unity to diversity.'

According to Tadeusz Paleczny, 'one of the elements of Americanization, universalization of the identity of the members of monocentric groups, such as Korean, Japanese or Mexican ones, is the phenomenon of amalgamation. The Europeanization of Poles and Germans will also be fully realized only when there is a new, dominant type of double or polyvalent, multiple identity beyond the ethnic and national boundaries, formed through culturally mixed marriages'(Paleczny, 2007).

The aim of the research is an academic description of binational marriages which have been concluded by spouses from different nationalities, and thus characterized by different culture, tradition, mother tongue, and often religion and race, one of them being the representative of Polish culture. 
The following research problems will be analysed: decision-making processes, fields of eligibility, plans for the future, problems occurring within the binational marriages, ways of dealing with differences or difficulties resulting from binational relationships, the quality and durability of marriages, the quality of relationships in a marriage.

The accepted hypothesis assumes that in binational marriages problems often arise due to cultural diversity of the spouses, which makes the durability and quality of binational marriages lower than mononational marriages.

While conducting a study on binational marriages, the researcher is confronted with difficult tasks. A multitude of research problems and a wide range of issues make the researcher relate to a number of academic fields.

The research methods which were used are: diagnostic survey and individual case study. Diagnostic survey method was chosen as a basic method in the research, under which it was decided to use the techniques of observation, questionnaire, interview and statistical techniques. These techniques were defined more clearly and expressed by means of research tools such as: a questionnaire and an interview constructed independently by the author. The Scale of Quality and Durability of Marriage by M. Ryś; Matching Marriage Questionnaire selected by M. Plopa, J. Rostowski.

\section{Mixed marriages}

Nowadays, mostly due to the Internet and increasingly easier communication between various countries, we are observing the so-called 'shrinking' of the world, and consequently an increase in the number of people who fall in love with people from distant countries and get involved with them on a permanent basis. Accordingly, couples of mixed nationality (binational couples) are increasingly becoming a subject of scientific research.

The term 'binational marriage' means a registered relationship entered into by the citizens of two different countries. Marriages between foreigners are a kind of an indicator of openness of a society to contacts with other countries, indirectly also indicating the scale of long-term emigration or immigration, which may lead to the possibility of a permanent, intimate bond between citizens of the two states (Szukalski, 2013).

When people from different nations join together to make a couple, very important phenomena and processes occur, whose significance goes beyond the fate of the members of the couple. As a result of the amalgamation, that is a merger of cultural groups following a marriage and the creation of hybrid forms of kinship, a new cultural order emerges. 
One of the very basic issues of family social sciences is the question of how do the partners experience love (Collet, 2012). In our deliberations we are also interested in motives of a binational marriage.

Beate Collet lists a number of reasons, which are not exhaustive or exclusive of course: Feeling alone, need for help or assistance and/or founding a family. For people living in a foreign country the motives might be more complex than the ones mentioned before. Due to their legally or politically precarious position, they might be searching for a job and social integration, they might not speak the local language, might feel different, discriminated against and/or even persecuted. She further states that from the perspective of a local an intimate relationship with a foreigner, hence a member of a minority group, is in some aspects "special". To love the person might be mistaken for caring for the person. The "Romeo and Juliet complex" might also play an important role, because "love is more intense" when your partner is discriminated against or when the relationship is on unstable ground because it is legally difficult and socially rejected (Collet, 2012).

Initially, research into ethnically mixed marriages was conducted mainly in the United States and other classic countries of immigration. However, in 2006, two Dutch professors, Matthijs Kalmijn and Frank van Tubergen, published the findings of their research on ethnic marriages among the citizens of Suriname and the Netherlands Antilles ${ }^{1}$, Turks and Moroccans in the Netherlands. For the authors, it was important to examine from the theoretical and empirical perspective whether the patterns observed earlier in the countries of traditional immigrants would be equally applied in the Dutch social context. In order to obtain a sufficiently large research sample, five representative national groups were selected, among which research was conducted between 1988 and 2002 (Kalmijn, van Tubergen, 2006).

Kalmijn and Tubergen distinguished three major sociological factors affecting the decision to enter into a mixed marriage: individual preferences concerning the features that a candidate for a spouse should possess, the number of opportunities to meet and the influence of third parties.

Sofia Gaspar argues that a binational marriage between two EU-partners is a different phenomenon than a binational marriage between an EU-partner with a non-EU spouse altogether. In an attempt to understand European intermarriages as a social phenomenon in its own right, she undertook a qualitative survey of 30 in-depth interviews with couples in Lisbon. She lists several advantages for couples with European nationality, such as the right of

The Netherlands Antilles was the Dutch autonomous territory in the Lesser Antilles (Central America) covering the 5 islands in the Caribbean Sea: Curacao, Bonaire, Saba, St. Eustatius and the southern part of St Maarten, existing in the years 1848-2010. 
abode, geographical mobility, civil rights, legally guaranteed freedom from discrimination and easier access to employment in comparison to other immigrant groups. She further states that as an EU citizen, marrying someone from another EU country would not require the legal and security procedures that apply for non-EU spouses when pursuing to obtain citizenship and then having the freedom of movement within the EU. Without a detailed explanation she draws the conclusion that "European intra-marriage rather involves personal motives such as love and affection than legal and economic factors that might be hidden in other types of transnational unions" (Gaspar, 2010).

A weak point in Gaspar's study, which she admits at the end of her study, is the fact that she interviewed highly educated people only. Since any level of educational degree can be found amongst the population of binational marriages, the shortcoming of the foreign towards the native spouse should have been addressed in more detail, as this would probably highlight other yet hidden aspects (Gaspar, 2010). Interestingly Gaspar's distinction between non-EU spouses and EU spouses seems to fit the Polish conception as well. The "bilateral negotiations" are the source for this harmonisation with inner European movement possibilities. It remains to be seen if "mass-immigration initiative" and its aftermath will have a negative impact on the relatively facile immigration procedures for EU-spouses.

\section{International migrations and nationally mixed marriages in Poland}

In the post-war history of Poland, a permanent settlement in our country of a person of a different nationality was mainly a consequence of marriage to a Polish citizen and the decision to live in the country of origin of one's spouse (Kępińska, 2001). Between 1945 and 1989 in Poland there were few mixed marriages, which was connected with the then political situation. Marriages by Polish citizens were concluded mainly with foreigners who undertook studies in Poland on the basis of international agreements.

After 1989, the scale of permanent immigration to Poland began to grow rapidly, the foreigners' motives to settle in Poland changed, too, as well as the countries of immigrants' origin. However, intermarriage was still an important reason for remaining in Poland for good. Two basic trends may be singled out that have shaped the phenomenon of mixed marriages in Poland in the 1990s. Although the total number of marriages between foreigners and Polish citizens in Poland between 1989 and 1997 was relatively stable (average of 3.2 thousand per year), their structure by country of origin and gender of the foreigner underwent remarkable changes. First of all, the percentage of Polish citizens married to the citizens of European countries (excluding the former USSR) 
decreased in this period, while the percentage of Poles married to the citizens of the USSR and the countries of the former Soviet Union - increased.

After joining the European Union, Poland has become a 'matrimonially' attractive country for non-EU citizens who through marriage may acquire Polish citizenship.

Both phenomena: international migrations and nationally mixed marriages are dynamic processes, whose existence, development and change is affected by various groups of factors. Both phenomena are associated with making decisions which are binding for the life of an individual and both of them take into account the rationality of the individual, but they also point to a driving force of boundary conditions. Both phenomena also show the interdependence between individual characteristics and boundary conditions, which are being shaped while influencing each other. Finally, both phenomena situate the decisions taken by an individual in terms of maximizing benefits and minimizing costs. Regardless of whether the goal is marriage or migration, we can talk about the choice of a life strategy, whose primary aim is to achieve the greatest benefits that outweigh potential losses.

The number of bicultural marriages in a given society can be treated as a determinant of the degree of assimilation of minorities: the more mixed marriages, the greater the integration of minorities with the national and cultural majority.

\section{Binational marriages among Polish scholars}

Mixed marriage is a relatively new research topic among Polish scholars. Until now, the study of binational marriages has been taken up by:

- $\quad$ E. Kępińska who, in 2001, published the results of her research (based on 10 in-depth interviews) into the mechanisms of settlement migration, exemplified by Polish - Ukrainian marriages;

- M. Walczak who, in 2001, published her research into the psychological prospects for the durability of bicultural married couples living in Poland;

- M. Jodłowska-Herudzińska, who, also in 2001, published the findings of her study on partnerships in cross-cultural mixed marriages. Her analysis was based on 30 free and in-depth interviews, including eight case studies of Polish-Asian and Polish-African married couples residing in Poland. In 2002 she published the results of a study on marital selection in cross-cultural mixed marriages;

- M. Małek, who, in 2009, published a study on the structure of mono cultural marriages (Polish) and mixed. 
According to Małgorzata Jodłowska-Herudzińska (2000), in mixed marriages a specific situation is created - the 'meeting', the binding of culturally distant partners who decide to enter into a marriage and thus to cohabitate, to cooperate for the good of the family, which means mainly children upbringing and mutual help (Jodłowska, 2000). Cultural differences between spouses seem to be a significant independent variable determining the patterns of spouse selection, and the 'effect' of this choice may be a variable modifying the scope of danger that mixed marriages face because of their very nature (as far as the relationship between the final result of the selection and the quality and durability of a marriage are concerned).

Generally, it is believed that the degree of similarity between the spouses, in particular similarity of cultural characteristics, determines the success in marriage and marital satisfaction (Walczak, 2001). Heterogamy, primarily concerning such features as differences in nationality, religion or race constitutes a very heavy burden on marital and family life. What is more, it often does not meet with social approval, which almost always is given to endogamy. Usually, spouses belong to the same nation, live in the same place, have a similar level of education, are often part of the same professional category and have similar social origins (Jodłowska-Herudzińska, 2002).

\section{Multicultural environment}

Marrying a person from a different culture provides the ability to overcome personal stereotypes. Multicultural marriages (and the experience of interacting with people from different cultures) make both partners aware of the prejudices they have, while most people do not realize that they possess them (Alupoacei, 2009). However, the fact is that mixed marriages are difficult, as discord and problems with acceptance may arise even before the marriage is concluded and may cause great tensions during it, leading not only to disorganization of the marriage, but also to its disintegration (Jodłowska-Herudzińska, 2002). On the other hand, through its homogeneity, endogamy does not free a marriage of the incompatibility of views. Thus, we could say that culturally mixed marriages are a more difficult but also a more interesting option.

The degree of cultural difference determines the number of problems which occur between partners. National, religious, linguistic and cultural differences can affect both positively and negatively a partnership or marriage. The result is conditioned, among others, by the degree of the similarity of a partner, the degree of language barrier, the acceptance of a different culture and religion of the partner and his or her distinct views. 
As with any inter-cultural contact, in mixed couples there must come to a kind of a compromise - the partners learn about each other's culture and together they create a mixture that enables them a harmonious coexistence. Under the influence of cultural compromise, which takes place in mixed relationships, partners, adapting to each other, may change their habits, customs, ways of behaviour, opinions, values.

The following factors may lead to problems in mixed relationships: differences of national cultures, the assumption of similarity of interlocutors, language differences, incorrect interpretation of non-verbal signals, stereotypes and prejudices, different system of values, fears and tension, uncertainty and stress, ethnocentrism and conviction of the 'superiority' of one's own culture, a culture shock, religious diversity or even cultural models to satisfy hunger.

A foreigner is often subject to prejudice and stereotypes. Römling (2013) identifies several external stress factors for binational relationships related to stereotypes and prejudice behaviour of the local population. Racism and sexism in regard to skin colour, distinct facial features and other racial associated properties constitute only the first points in her analysis. She reports also discrimination during the job search as well as at the working place of the foreign spouse. The previously described questionable interfering authoritarian power of the state is also among her key points (accusation of sham marriage). In the same category falls the unsecure legal situation of the foreign spouse. Furthermore she describes the difficult situation a foreign spouse faces in their partners friend circle and especially in his/her family surroundings. The couple is urged to prove their relationship and the durability of their marriage (Römling 2013).

\section{Own research}

The research were conducted among binational married couples living on the entire territory of Poland. The research was conducted on a sample of 40 people (10 binational married couples and 10 Polish married couples). The research shows that binational married couples do not differ in their assessments of happiness, quality and durability of their relationship as compared to Polish ones. A comparison of men and women revealed that in this type of relationship it is the wives, more often than husbands, who feel burdened by a factor of biculturalism, which makes them perceive their marriages as less integrated, less satisfactory and having a poorer communication between spouses.

It also follows from the research that for the respondents of both Polish and foreign origin, the idea of partnership in marriage is possible, despite differences in terms of its definition, which may have the source even in the gender of the respondents - spouses of foreign origin are predominantly male. 
The analysed marriages were heterogeneous in terms of such characteristics as nationality, race and religion, which is a heavy encumbrance and foreshadows the difficulties that the candidates may face both during courtship, as well as during their marriage. Relationships of the type described here were much more often concluded by Polish women than by Polish men. Homogamy in these marriages in most cases related to education, social background, environmental origin, previous marital status. An unfavorable factor present in a considerable number of these marriages was a short period of having known each other before marriage.

However, there were more factors that may have a very positive impact on the the functioning of individual families, namely, in the great majority of cases: adulthood of the newlyweds, a high degree of skills enabling the spouses to cope with the language barrier, positive reactions of parents to their child's decision about marriage with a foreigner, a small age difference between spouses and positive type of motivation for entering into marriage.

\section{Summary}

Based on the own research, the following conclusions were assumed:

- Decision-making processes of people entering into bi-national marriages are different from the decision-making processes of people entering into mononational marriages;

- In terms of socio-demographic characteristics, bi-national marriages are mostly homogeneous marriages

- One group of the spouses have common plans for the future, while the other part of the spouses have different plans for the future;

- In binational marriages problems often arise due to cultural diversity of the spouses;

- Adaptation strategies aimed at dealing with cultural differences the most commonly used by spouses, is a strategy of compromise and a coexistence strategy;

- National origin will be a factor highly unfavourable for the implementation of the partnership model of marriage.

Binational couples have to overcome a number of social, cultural and financial obstacles. There is a need to form organizations that are assisting such couples by:

- personal counseling;

- $\quad$ advice and support for further problems such as bringing up children or a falling out between partners, etc.;

- information and education pertinent to the legal/formal aspects of a marriage, rights and duties of the partners according to the laws of their respective countries of origin, pointing to possible discrepancies concerning the partners' culture, religion, language or upbringing;

- $\quad$ helping a couple-to-be prior to marriage, or before starting life as an unmarried couple, to make this important decision in full awareness of the situation the couple may find itself in, and to help them openly discuss all aspects that may 
lead to serious misunderstandings;

- diagnosis of problems arising between partners having their possible origin in different cultural backgrounds with the possibility of passing on those concerned to organisations specialised in family mediation, family counseling, family therapy, etc.;

- $\quad$ in cases of separation or divorce, providing information on pertinent foreign legal aspects with a special eye on guaranteeing the well-being and rights of the couple's children;

- networking/cooperation with additional counseling units/call centers for binational and non-Polish couples living in Poland;

- $\quad$ legal representation of non-Polish nationals (law on foreigners);

- $\quad$ setting up and maintaining a website in conjunction with additional organisations active in the field.

\section{References}

Alupoacei, M. (2009). Your intercultural marriage. A guide to a healthy, happy relationship. Chicago:Moody Publishers.

Collet, B. (2012). Mixed couples in France. Statistical facts, definitions, and social reality. GEMASS Université Paris IV-Sorbonne, 97/1, 61-71.

Gaspar, S. (2010). Family and social dynamics among European mixed couples. Portuguese Journal of Social Science, Vol. 9, Nr. 2, 109-125.

Jodłowska, M. (2000). Konflikty w międzykulturowych małżeństwach mieszanych. In: Tyszka, Z. (Eds.) Współczesne rodziny polskie - ich stan i kierunek przemian (pp. 215231). Poznań: Wydawnictwo UAM.

Jodłowska-Herudzińska, M. (2002). Kwestie doboru małżeńskiego w międzykulturowych małżeństwach mieszanych, życie rodzinne - uwarunkowania makro i mikrostrukturalne. Roczniki Socjologii Rodziny XIV, 14.

Kalmijn, M., \& van Tubergen, F. (2006). Ethnic intermarriage in the Netherlands: confirmations and refutations of accepted insights. European Journal of Population / Revue européenne de Démographie, Vol. 22, Issue 4, 371-397.

Kępińska, E. (2001). Mechanizmy migracji osiedleńczych na przykładzie małżeństw polskoukraińskich. Prace migracyjne, 40.

Paleczny, T. (2007). Interpersonalne stosunki międzykulturowe, Kraków: Wydawnictwo Uniwersytetu Jagiellońskiego.

Szukalski, P. (2013). Małżeństwa binacjonalne. Demografia i Gerontologia Społeczna Biuletyn Informacyjny, 3, 1-5.

Walczak, M. (2001). Psychologiczna prognoza trwałości matżeństw dwukullurowych, Problemy Rodziny, 1, 22-28. 